\title{
Research on Undergraduate Students' Entrepreneurship Support System in Private Universities
}

\author{
$\mathrm{Na} \mathrm{Li}$ \\ Shandong Xiehe University \\ Jinan, 250100, China \\ Lina0704@126.com
}

\begin{abstract}
Self-employment of college students is an important measure to ease employment pressure and reduce social burden. University training is an important guarantee to improve the success rate of students' entrepreneurship. Especially private undergraduate colleges, a distinctive entrepreneurial support system, can not only train students, but also enhance their core competitiveness. Through expounding the relationship between private colleges and university students' entrepreneurship support system, this paper studies the plight of establishing entrepreneurial support system to ease the difficulties of college students' entrepreneurship. The undergraduate entrepreneurship support system in private universities includes deepening the concept of entrepreneurial university, improving entrepreneurship education, setting up project recommendation platform and improving enterprise support system. The system can improve the entrepreneurial awareness and entrepreneurial success rate of college students, and can effectively reduce social burden.
\end{abstract}

Keywords-private college; undergraduate; entrepreneurial support

\section{INTRODUCTION}

Under the stern situation of college students' employment, self-employment has become the focus of all circles in society. The government work report of NPC \&CPPCC once stressed: to optimize the environment of employment and entrepreneurship, to led entrepreneurship by innovation, and to promote employment bye entrepreneurship. Therefore, it is an important measure to alleviate the employment pressure and lighten the social burden by constructing the university students' entrepreneurship support system and cultivating their entrepreneurial consciousness and ability [1]. Especially private undergraduate colleges, a distinctive entrepreneurial support system, can not only train students, but also enhance their core competitiveness.

College entrepreneurship support system is an organized whole which provides support, service and guarantee for college students through direct impact on them or the improvement of entrepreneurial environment. It is generally composed of three sides, universities, enterprises and government. Government support is mainly policy support,

This study is supported by Shandong Provincial Social Science Planning and Management Office (No. 16CGLJ30) and Shandong Xiehe University (No. 2015xh08) platform support and fund support. Corporate support is mainly financial support, experience support and relationship support. However, the support of colleges and universities mainly includes education support, concept support and experience support. This paper intends to study the components of entrepreneurial support system from the perspective of private universities.

\section{THE RELATIONSHIP BETWEEN PRIVATE COLLEGES AND} UNIVERSITY STUDENTS' ENTREPRENEURIAL SUPPORT SYSTEM

The cultivation of college students' entrepreneurial ability is mainly through the entrepreneurship education. The entrepreneurial theory, knowledge, skills and qualities need to be received through the relevant education in colleges and universities. Private colleges and universities not only focus on theory teaching, also attaches importance to business practice and the cultivation of students' ability. So its role in cultivating students and promote the harmonious development of the society is increasing. And it gradually becomes the main body of innovation and entrepreneurial talent training. Private colleges need to think how to construct entrepreneurial support system in from different angles. It not only needs to improve entrepreneurship education, also needs to establish a project recommendation platform that can support students entrepreneurship competition, and also needs to improve the business support system. The business support system is a system that has a business platform for interaction, and it takes the enterprise subsidy as the leading factor, the student as the implementation subject. The relation between university and students' entrepreneurship support system is shown in Fig. 1.

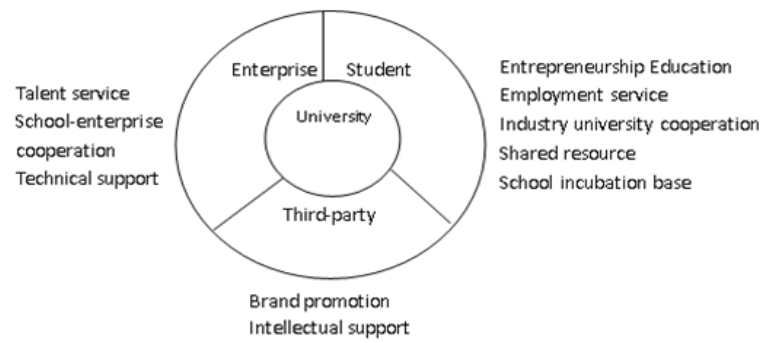

Fig. 1 The relation between university and students' entrepreneurship support system 


\section{THE CONSTRUCTION OF ENTREPRENEURSHIP SUPPORT SYSTEM IN PRIVATE COLLEGES AND UNIVERSITIES}

\section{A. Deepening the concept of "entrepreneurial" university}

The entrepreneurial university plays a very important role in promoting entrepreneurship in the aspects of entrepreneurial innovation, cultural penetration and entrepreneurial intelligence support. University can play an important basic role in college students' entrepreneurship by using the concept of "entrepreneurial" university to deepen the idea of running a school and the reform of education and teaching.

Entrepreneurial universities, while stressing the two elements of technology transfer and organizational transformation, should also emphasize the factor of knowledge innovation. Knowledge innovation is the logical starting point of technology transfer and organization transformation, and it is also the essential factor for the generation of entrepreneurial university. This is because entrepreneurial universities are the places to concentrate their knowledge. The United Nations defines technology transfer as "the transfer of systematic knowledge", and technology transfer needs to be based on a large number of new knowledge and discoveries. Stanford University is an example of entrepreneurial universities and a model of knowledge innovation. Our country should combine the successful practice of entrepreneurial university development experience of European countries and some domestic universities, attaches great importance to the transformation of entrepreneurial university, and focus on the construction of a number of entrepreneurial university that are different styles and different levels. We should fully digest, absorb and refine original knowledge, and apply it to enterprise practice, then promote the flow, transformation and application of practical knowledge and technology in the whole society.

The university should choose the entrepreneurial road which is suitable for university development according to its own advantages and characteristics. Different types of colleges and universities have difference in its content, extension and characteristics when they serve society. Whether the American model that takes university business activities as the research extension, or the European model that takes university entrepreneurship as teaching extension, the organizational transformation and entrepreneurial activities echo social and economic needs in external manifestation. Its internal purpose is to promote the research and teaching of the university, and then promote the innovation of knowledge and the idea and mode of personnel training. On the whole, European and American entrepreneurial universities rarely establish and control enterprise entities directly. And they are very wary of attempts to promote technology transfer and increase revenues by university formation companies. The main way of entrepreneurial activity is just play " radiation source " and "incubator" function of college talent and technology, through the transfer of patents, research funding from the government, the enterprise competition, or is derived by incubation enterprises, small independent companies, accounting for a certain amount of equity holdings and fees for the use of patents realization of university technology transfer. On the one hand, universities have trained a large number of entrepreneurs and management technicians to promote the innovation of high-tech industries, and they have promoted the transfer of knowledge and technology. On the other hand, universities can transfer knowledge and technology achievements by transformation of internal organizations through market intermediaries timely. As an example of an entrepreneurial university, Stanford University insists on not setting up its own business and emphasizes the transfer of technology to enterprises. Entrepreneurial universities in Europe and America combine entrepreneurial activities with the fundamental goal of promoting research and teaching, according to the characteristics of the university itself, to realize the transfer of technology and the industrialization of knowledge by the internal organization transformation and the mature market operation mechanism. Eventually reach a tripartite win-win situation of university, government and society. Our country should draw lessons from the mode and development experience of international entrepreneurial universities on the basis of the experience and lessons of the school owned enterprises which are directly controlled by the former universities. On the one hand, we should strengthen the entrepreneurial leadership ability, innovate the operation mechanism of entrepreneurial organizations, and realize the technological transfer of universities. On the other hand, we should give more autonomy to universities, promote knowledge innovation and technological transfer of universities, choose a path with distinctive personality, and finally achieve a successful transformation from an entrepreneurial university.

\section{B. Improving the business-pioneering education}

It is necessary for college students to improve their own entrepreneurship education so as to cultivate their awareness of self-employment. There may not be many students who have been successful entrepreneurship in their studies, but schools can train a large number of students with entrepreneurial awareness through entrepreneurship education. The entrepreneurship education in colleges and universities includes offering entrepreneurship courses, conducting practical entrepreneurship guidance, and setting up college student entrepreneurship associations [2]. First of all, entrepreneurship courses should be set up to cultivate college students' awareness of entrepreneurship. Core courses should focus on entrepreneurial activities. And supplementary courses should be related to entrepreneurship or to support entrepreneurship. At the same time, the related courses of entrepreneurship education should be continuously improved and expanded. Mainly refers to the expansion of entrepreneurship in the field of courses and research content, either to increase new entrepreneurship courses, or to modify existing entrepreneurship courses. In the field of related research, in-depth study of entrepreneurial activities, and import ideas in general education. Integrating entrepreneurship education into general education courses, and the core courses of entrepreneurship into compulsory courses for undergraduate students. Then, guiding for the practice of entrepreneurship, and establishing student entrepreneurship association, to stimulate entrepreneurial enthusiasm of college students. Private colleges and universities can build a specific business environment in the campus, and set operating standards or norms, allowing students to independently carry out related business activities. In the course of students' management, the 
entrepreneurs should give reasonable and proper guidance. School business practice is a method that schools can make full use of their own resources in order to stimulate students' awareness of entrepreneurship, encourage innovation and provide practical opportunities [3]. Schools can provide a set of practical exercises places for college students, including guidance and counseling services about business, credit, taxation, project evaluation approval et, also including all kinds of intermediary services about financial consulting, information consulting, property transactions and asset appraisal et to provide students with accompanying entrepreneurial counseling.

\section{Focusing on the construction of entrepreneurial incubation base}

The college students' incubation base is an attempt to creatively solve the problem of college students' employment, its functions include:

(1) R \& D innovation. University Students incubation base provides financial and policy support for $\mathrm{R} \& \mathrm{D}$ innovation through project selection and project incubation to encourage students to bring laboratory research results and innovative projects to the base for further research and development. Making the innovation achievement to realize the industrialization in the quickest way, and form the new knowledge flow and technology flow.

(2) Enterprise incubation. University students incubation base constructs an entrepreneurial platform suitable for enterprise development through a complete support service system and integration of service resources. Through the provision of law, taxation, finance and other services to help start-ups avoid venture capital, and improve the survival rate of enterprises. Expanding entrepreneurial enterprises through the project docking.

(3) Cultivation of entrepreneurial talents. Entrepreneurial base not only provides systematic entrepreneurship training for entrepreneurs, but more importantly, entrepreneurs can start their business practice at the base. Through real entrepreneurial activities, to further develop their proficiency. This training model is an important complement to school education. Through "learning in doing" and practice to sum up experience, so that entrepreneurial incubator base to become the cradle of entrepreneurial talents and entrepreneurs.

Entrepreneurial incubator base is the material foundation for college students to start their business. College students' science and technology parks and university derivative enterprises are important bases for college students to start their own businesses. It will provide a good ecological environment and an effective carrier for college students to start their own businesses [4]. On the one hand, colleges together with the government and enterprises, create a pioneering park for college students, and give full play to the advantages of talents, technology and resources in universities. Efforts should be made to promote the cooperation between schools and enterprises, and accelerate the establishment of the incubator base that can provide consultation, guidance, training and achievement transformation, also a national, provincial, public welfare, demonstration and professional one. It provides a platform for entrepreneurial project incubation and technological achievements transformation for college students. And in the form of intellectual support to take part in college students' entrepreneurship with more specific and deeper. On the other hand, colleges and universities rely on their own skills and talents to create derivative enterprises, including which founded by school graduates, transferred by university technology transfer, and enterprises with employee stock holding by universities and enterprises established by their own staff. To create a "Silicon Valley" model with Chinese characteristics, making it the center of financing media, thus winning diversified sources of funding and creating a favorable environment for college students' entrepreneurship.

\section{Strengthening the construction of campus entrepreneurial culture}

Creating a cultural atmosphere of innovation and entrepreneurship is necessary for college students to start their own businesses. Only when the culture of college students is recognized in the whole campus, will it be easy to implement the reform of the university in operation and teaching, and the efforts of students and teachers in innovation and entrepreneurship will be stimulated [5]. Entrepreneurial culture may initially be a simple institutional concept. But through the university together with student association, Communist Youth League organizations, social service organizations, enterprise and local governments to carry out entrepreneurial policy advocacy, business model, introduces the practice of entrepreneurship, business plan competition, enterprise practice, and simulation of enterprise management activities, this will eventually become a cultural character and symbol for university, and will greatly promote the development of the college students' entrepreneurship.

\section{E. Improve the enterprise support system, especially the support of minor enterprise.}

Including the establishment of interactive platform for entrepreneurship, and the enterprise support system that is taking the enterprise subsidy as the leading factor, the student is the implementation subject. The best way for college students to learn the knowledge of entrepreneurship is to combine learning with real entrepreneurial activities [6]. It means that small and medium-sized enterprises close to the actual entrepreneurial situation are the best choice for entrepreneurs to learn and start business. In small and medium enterprises, college students can achieve "learning by doing". That is, learning entrepreneurial knowledge from everyone, everything, and even every detail, including how companies coordinate resources, how to relate internal and external environments, and how to produce products and provide services. Therefore, private colleges and universities should establish an interactive platform with enterprise, and hire entrepreneurs to attend business lectures regularly, to develop knowledge of entrepreneurship for college students, and teach their own entrepreneurial experience. At the same time, students will be organized to visit and practice, and they can experience the problems that may arise in enterprise operations. Through the interaction between college students and entrepreneurs, the deficiency of theoretical knowledge can be compensated, and long-term cooperation with enterprises will 
be established. Excellent college students should be funded by enterprises to form a new generation of entrepreneurs, and then back to school, so as to achieve a virtuous circle. Colleges and universities can also directly invest in the establishment of enterprises, and then allow students to participate in the management of industry companies. And make full use of the resources both inside and outside the school, and perfect the construction of practice bases for college students.

The composition of entrepreneurial support system is as table I:

TABLE I COMPOSITION OF ENTREPRENEURIAL SUPPORT SYSTEM

\begin{tabular}{|l|l|}
\hline Entrepreneurship support system & \multicolumn{1}{c|}{ Concrete content } \\
\hline Entrepreneurial university concept & $\begin{array}{l}\text { Technology transfer Organizational } \\
\text { transformation } \\
\text { Knowledge innovation }\end{array}$ \\
\hline Entrepreneurship education & $\begin{array}{l}\text { Entrepreneurship course } \\
\text { Entrepreneurship practice }\end{array}$ \\
\hline Incubator base & $\begin{array}{l}\text { College Students Pioneer Park } \\
\text { University derivative Enterprises }\end{array}$ \\
\hline Campus entrepreneurial culture & $\begin{array}{l}\text { Theory of regulations } \\
\text { cultural atmosphere }\end{array}$ \\
\hline Enterprise support system & $\begin{array}{l}\text { Entrepreneurial interactive platform } \\
\text { Corporate finance } \\
\text { Student implementation }\end{array}$ \\
\hline
\end{tabular}

\section{CONCLUSION}

In short, all the policies and entrepreneurship education of private undergraduate universities should start with the actual needs of college students and make adjustments according to the needs of the times and social development. As a new thing in China, the development of college students still needs to be explored, which needs more attention and support from the government, society, colleges and universities and everyone.

\section{REFERENCES}

[1] Knake, Renee Newman. Why Law Students Should Be Thinking About Entrepreneurship and Innovation in Legal Services [J]. Bloomberg Law, November 30, 2012:1-2

[2] Ji Zhenqi, Zhou Feng. Practice of entrepreneurship education [M]. Higher education press, 2014 (3): 5 - 7(In Chinese).

[3] Liu Chunyan, Wei Zhanbing, Liu Jianchao. Practice of teaching staff construction of innovation and entrepreneurship education in Higher Vocational Colleges [J]. Operation and management, 2015 (8):135 (In Chinese).

[4] He Yubing, Ding jimin. How do entrepreneurial universities construct an ecosystem of entrepreneurship education [J]. Science research, 2015 (7):1043(In Chinese).

[5] Zhu Jian. Promoting entrepreneurship education in Colleges and universities with entrepreneurship. [J]. ideological and theoretical education, 2015 (4):88(In Chinese).

[6] Zhang Xiue, Fang Zhuo. Study on the mechanism of College Students' entrepreneurial behavior [J]. Journal of Jilin Normal University, 2015 (4):102 (In Chinese). 